Journal of Critical Race Inquiry

Volume 7, Number 2 (2020) pp. 46-73

\title{
Framing the Truth and Reconciliation Commission Process in Canada: A Media Analysis of Settler Colonial Rhetoric and Colonial Denial, 2003-2016
}

\author{
Laura Mudde \\ University of British Columbia (Okanagan)
}

\begin{abstract}
The Truth and Reconciliation Commission (TRC) of Canada helped to expose the trauma experienced by Indigenous peoples in Canada's Indian Residential Schools (IRS), which were governed and run by government and church officials. In 2008, the Canadian government formally apologized for these residential schools. This apology was undermined, however, by a denial of colonial history by Canada at the G20 in 2009, revealing a rhetorical contradiction that is part of a public narrative of colonial denial. This paper examines the public discourse during and after the TRC process to understand the impact of negative discourses regarding the TRC and colonialism. This case study examines written content from five Canadian media platforms that covered the Alternative Dispute Resolution (ADR) and TRC process between 2003 and 2016. Drawing on concepts such as the white possessive, white rage, and white fragility, the aim of this paper is to unpack the cognitive dissonance of apology concurrent with the rhetoric of settler colonial denial. Findings from the discourse analysis substantiate the hypothesis that continued dominant narratives of settler colonialism align with representations of the TRC process. This limits the authentic potential for a formal apology to address the IRS legacy which perpetuates continued settler colonial realities in Canada.
\end{abstract}

Keywords: white possessive, white rage, white fragility, cognitive framing, settler colonialism, denial, racialization, rhetoric, media, Truth and Reconciliation Commision 


\section{Introduction}

The 2008 Truth and Reconciliation Commission (TRC) set out to inform Canadians about the Indian Residential Schools system (IRS) and to promote reconciliation between Indigenous and Canadian peoples. It contained a settlement package for survivor compensation endorsed by the Indian Residential Schools Settlement Agreement (IRSSA), following the Alternative Dispute Resolution (ADR) (McLellan, 2005). ${ }^{1}$ The operating mandate, Schedule N of the IRSSA (2008), sought to "contribute to truth, healing, and reconciliation" (p. 1). ${ }^{2}$ However, the TRC experienced bureaucratic and legal barriers involving the government and church denominations that had been responsible for running and governing the IRS system. The commission faced conflicts resulting in the resignation of its commissioners in 2008. In 2009, three new commissioners had to re-establish the commission, regain trust with Indigenous communities and individuals, and re-foster support from the Canadian public. Regrettably, these internal and legal struggles of the commissionrather than the operating mandate-garnered the most attention in media coverage on the TRC between 2008 and 2016.

This media coverage requires further review to inspect the racialized narratives that it conveyed to the public. This paper provides a case study of five Canadian news platforms covering the TRC and of the settler colonial ideology embedded therein. Settler colonial ideology, in line with definitions from Wolfe (2006), Moreton-Robinson, Casey, and Nicoll (2008), and Moreton-Robinson (2015) is a normative societal construct based on an ongoing structure of power that systematically erases Indigenous peoples. This ideology, its rhetoric, and affected public discourses are themselves often rendered invisible in favour of pioneer settler histories (Furniss, 1999). This normative settler colonial ideology, I argue, shapes the public discourses regarding the TRC, which extends denial of settler colonialism in Canada. This case study highlights settler colonial ideology through the discourse analysis of over 1,000 news sources. The settler colonial rhetoric unveiled reveals the white properties of settler colonialism, as well as the possessive discourse inherent in settler colonial ideology in Canada (Harris, 1993; Moreton-Robinson, 2015; Moreton-Robinson et al., 2008). Newspaper

\footnotetext{
${ }^{1}$ To view the Settlement Agreement, the schedules to the Settlement Agreement, and the Agreement in Principle, see http://www.residentialschoolsettlement.ca/settlement.html. Initially, the TRC had five years and a $\$ 60$ million budget for this settlement package.

2 This mandate was further detailed, but not limited to, acknowledging residential school experiences, witnessing through truth and reconciliation events, promoting awareness and education, collecting historical records, report and recommend on the ongoing legacy, and support commemoration for former students and their respective families (Schedule N, pp. 1-2).
} 
articles analyzed through this research expose the white rage (Anderson, 2016) and white fragility (DiAngelo, 2018) in responses to the TRC process.

This case study is vital to expand the existing literature on the properties of the white possessive, white fragility, and white rage, specifically in Canada. This assessment highlights how the Canadian press disseminates racialized imaginaries, and substantiates the need for a more critical assessment of the continued mechanisms of colonial denial in the public domain, specific to Canada. Scholarship on the properties of the white possessive, white fragility, and white rage (Anderson, 2016; DiAngelo, 2018; Harris, 1993; Moreton-Robinson, 2015; Moreton-Robinson et al., 2008), I argue, should be combined with a public discourse metaanalysis. The analysis of the public sphere and settler colonial ideology represented therein require a more critical conceptualization specific to Canada (Brady \& Kelly, 2017; Storey, 2016; Tolley, 2016).

Responses to the TRC process highlight the nuanced ways in which the representation of settler colonial ideology occurs in the Canadian public sphere. This inquiry promotes an indepth analysis of the subtleties of settler colonialism circulated in the public sphere in Canada. A critical approach to normative narratives reveals how public sources are politically and racially driven and do not account for the structural settler colonial realities, as seen in coverage on the TRC. In following sections, I explore how the five news outlets reported on the TRC process; how representations of the TRC process form part of a broader narrative regarding Indigenous peoples; how public narratives denounce Canada's colonialism; and how apologies for the IRS system and public outrage coexist with a denial of Canadian settler colonialism. First, I provide a short background review of the TRC process in Canada. Second, I review the literature on the white possessive (Harris, 1993; Moreton-Robinson, 2015; Moreton-Robinson et al., 2008), settler colonial denial (Dunbar-Ortiz \& Gilio-Whitaker, 2016), and racial bias disseminated and perpetuated in our collective memory. After a synopsis of the methodological approach, the final sections centre the case study results and critical assessment.

\section{Background}

Structural racialization had been institutionalized in Canada well before the establishment of the IRS system. As Milloy (1999) and Andersen and Walter (2013) assess, institutionalized Aboriginal ancestry and identity originated in the Royal Proclamation of 1763 and the amalgamation of racialized law in the Indian Act of 1876. The colonial office, Canadian government, and the Department of Indian Affairs (DIA) stipulated who was and 
was not an "Indian" [ $\mathrm{sic}]$ (Fisher, 1980). The political institutions to promote settler society policed and curtailed Indigenous existence, which furthered institutionalized racialization in the $19^{\text {th }}$ and $20^{\text {th }}$ centuries (Carter, 1990; see also Harris, 1993). The system that emerged categorized the inhabitants of the Canadian interior according to "scientific racism" based on stereotypes still in use today (Little \& McGivern, 2016). This racialization is visible in Canadian institutional reports but also in the public sphere, as stereotypes of Indigenous peoples can be traced to early $18^{\text {th }}$ century categorizations shaped by economic incentives for European and American settlement over Indigenous settlement (Fisher, 1980; Loppie, Reading \& de Leeuw, 2014 ).

The TRC, set in motion by the Royal Commission on Aboriginal Peoples (RCAP, 1996), did not provide critical inquiry into these stereotypes or tropes of settler memory. According to Tarrow (1993) the TRC, like the RCAP, does not invoke critical responses or assessments of stereotypes as presented in public discourses dominated by non-Indigenous Canadian rhetoric. Consequently, the acknowledgment of structural settler colonial implications in lengthy reports of the RCAP and TRC has failed to gain centrality in public discourses. It remains low in hierarchical significance and salience. These commissions do not alter structural racialization inherent to the Canadian settler colonial ideology, nor do they elicit non-Indigenous accountability for a system conducive to residential schools that upholds racial stratification (Harris, 1993, p. 1774).

This lack of accountability became visible in the TRC process itself. Besides the TRC's internal challenges, societal challenges were erased from the public eye. For instance, the noncooperative stance of church entities and the Canadian government went mostly unaddressed. As stated in Schedule N, the historical record involved the recall and request of documentary records from all entities involved. This recall of records resulted in multiple court cases and ongoing documentation collection issues (Truth and Reconciliation Commission, 2012, p. 16). According to the TRC interim report (2012), "Canada has not provided any proposal or signalled any intention of fulfilling its obligation to identify, organize and produce the Library and Archives Canada documents" (pp. 16-7), nor provided the TRC with enough funds.

Consequently, and due to this lack of cooperation by state and church entities, essential information is missing from the final reports. For example, residential school-related deaths are likely five to 10 times higher than reported but are covered up by non-existent or inadequate burial records held by church and state (CBC News, 2014). This lack of cooperation with the TRC reflects the normative and self-protective properties of the settler colonial system. Notably, news reports reinforce narratives of poor management by the TRC, rather than untangle the evasiveness of the settler colonial system and lack of cooperation. 
Regardless, the TRC continued its mandate and spent six years traveling throughout Canada to hear testimonies from over 6,500 witnesses. Additional national events intended "to engage the Canadian public, educate people about the history and legacy of the residential schools system, and share and honour the experiences of former students and their families" (Government of Canada, 2018). The TRC created a historical record of the IRS system, archived at the National Centre for Truth and Reconciliation at the University of Manitoba. The Final Report, Honouring the Truth, Reconciling for the Future, documents trauma and intergenerational terror experienced by roughly 150,000 Canadian residential school students (2015a). Additionally, the TRC produced six volumes on the IRS system. The Final Report (2015a) offered 94 recommendations or Calls to Action (2015b). These actions include the need for closer scrutiny and investigation into government cover-ups and neglect related to the IRS system.

\section{The "White" Possessive}

The RCAP and TRC are part of an intercultural dialogue reflected in public discourses in Canada. Even so, public representations constitute racialized narratives on Indigenous-nonIndigenous relations. Public discourses and media can be problematic as coverage is often inherently normative and settler colonialist (Holmes, Hunt \& Piedalue, 2014). Elucidating the normative power of settler colonial rhetoric in Canadian media is an essential intervention in understanding pervasive racialized public discourses (Tolley, 2017).

These settler colonial narratives dominate and continuously suppress Indigenous views. Tuhiwai Smith (1997) substantiates that the larger settler colonial belief system is obsessed with questions of "truth" and objectivity that match with settler colonial collective memory and experience. Majority-oriented non-Indigenous realities are often far removed from the Indigenous experience of existence, and realities expressed by Indigenous minorities are erased or ignored (Smith, 1997). What is more, in the context of the U.S., Harris (1993) writes that the ideological majority "cannot be burdened by inequities that are the product of history," indicating denial and erasure of Indigenous realities in favour of the settler colonial system (p. 1774).

This marginalization of Indigenous experience — and lack of settler colonial introspection - in Canadian society is problematic. Smith (2012) argues that "the lack of attention to settler colonialism hinders the analysis of race and white supremacy [and] hinders the development of a decolonization framework" (p. 66). This lack of attention to settler 
colonialism means related stereotypes go unacknowledged. Instead, discussions ensue focused on survivor compensation and change within Indigenous communities, ignoring the settler colonialist mechanisms that need deconstruction. As Harris (1993) points out, "the distortions in social relations are immunized from truly effective intervention, because the existing inequities are obscured and rendered nearly invisible" (p. 1777; see also Tarrow, 1993). Instead, settler colonial tropes persist, enforcing pioneer, frontier, and multicultural myths (Furniss, 1999).

Settler colonial-fueled racial bias in the Canadian context meant extraordinary measures were employed to remove Indigenous peoples from their territories (Smith, 2009). The territorial intentions shaped political framing of Indigenous peoples by the DIA (later INAC/Crown-Indigenous affairs), which in turn provided the racialized stereotypes and tropes perpetuated by government officials (Clark, 2014; Environics Institute for Survey Research, 2016; Fisher, 1980; Francoeur, 2018; Mudde, 2018). Territorial acquisition legitimated by tropes or stereotypes of racial inferiority justified measures to remove Indigenous territorial claims in favour of settler society and white virtue (Carter, 1990; Harris, 1993). The removal and erasure of Indigenous peoples are continuous, both in material consequences and symbolic representation (Smith, 2012).

As Moreton-Robinson (2015) demonstrates, "race" and "modernity" take shape through the normative politics of settler colonialism. Following Harris (1993), MoretonRobinson et al. (2008) and Moreton-Robinson (2015) suggest that whiteness shapes settler colonialism. Whiteness here is a socio-political and economic construct tied up with the appropriation and taking of territory as a fluid, aggressive, and reactionary mechanism of power. As Moreton-Robinson et al. (2008) attest, whiteness is possessive of the imperial nation-state "reinscribing social hierarchies through national imaginaries and their transgression" (p. xi). Whiteness, like settler colonialism in Canada, is an "invisible" racialized category that functions in multiple spaces and finds ways to continuously subjugate the Indigenous "Other" in favour of settler colonial possession. This racialized rhetoric is justified and grounded in the civilization narrative propped up by negative tropes regarding Indigenous people that shape "the cultural production of white virtue" (p. xi; see also Harris, 1993). It is important to note, however, that closer scrutiny of "whiteness" as a conceptoften seen in binary opposition to Blackness - is needed, as there are more complex layers of othering within the racialization of Canadian "whiteness." In this paper, I discuss "whiteness" as the oppressive systematic denial of colonialism within settler colonial society — not exclusively embodied or maintained by "white people." Importantly, whiteness must be understood not just as a "top-down" mechanism of state power and settler colonial 
imaginaries, as addressed in this paper, but also in the ways in which it is real and experienced in everyday interpersonal and intercultural interactions. And indeed, the latter also warrants more critical inquiry, but that is outside the scope of this research.

Settler colonialist rhetoric erases its embeddedness in enduring mechanisms of empire and race (Harris, 1993, p. 1778). Whereas research and resistance combat genesis amnesia of a settler colonial identity (Van Leeuwen, 2005), this is often met with denial of colonialism, white fragility, or even rage (see, for example, Harris, 1993, p. 1774, fn. 286). As MoretonRobinson et al. (2008) point out, whiteness is not a natural condition and therefore needs to be carefully guarded (p. 4; see also Smith, 2012). Denial, rage, and erasure of the settler colonial reality thus function as the self-protective premise of whiteness and white property (Harris, 1993).

The self-protective premise of whiteness is similarly distinguishable in political excuse and apology. According to Casey (2008), these excuses are a strategy to silence and appropriate Indigenous voices and resistance for continued imperial purposes (pp. 19-20). Apologies and denial of responsibility are also visible in total denials of colonialism, overall claims of racelessness, and "postcolonialism" by non-Indigenous actors (p. 22; see also Backhouse, 1999). This colour blindness (Harris, 1993, p. 1768), claims of multiculturalism (St. Denis, 2011), or false memory syndrome (Casey, 2008, p. 26) discards Indigenous testimonies as they discredit the hegemonic vision of the nation-state.

Moreover, Indigenous intergenerational trauma and the destruction of Indigenous livelihoods through the IRS system are placed in the past and disconnected from the continued settler colonial regime. Moreton-Robinson et al. (2008) explain that "revelations about violence within Indigenous communities [are] coupled with a failure to address the systemic and excessive character of violence against Indigenous people both past and present" (p. 66). Instead, after initial "outrage" about revelations regarding the violence faced by Indigenous people in the past, public discourses centre apologies only to circle back to the failure of Indigenous peoples to "govern themselves" and highlight Indigenous dysfunction.

This dysfunction in turn disengages settler colonial policies as causal structure. According to Moreton-Robinson (2015), "race and state operate in tandem to condition each other [in which] the regulatory mechanisms... are extremely busy reaffirming and reproducing this possessiveness through a process of perpetual Indigenous dispossession" (p. xi). This tandem feeds into public imagery and stereotypical tropes regarding Indigenous groups "overrepresented as always lacking, dysfunctional, alcoholic, violent, needy, and lazy" (p. xiii). It is white possessiveness that simultaneously perpetuates and denies settler colonialism as a constant reality (Harris, 1993; Smith, 2012; Wolfe, 2006). This settler colonial paradox is 
a structure that promotes a civilization narrative engrained in the larger belief system in Canada that justifies the continuous negative stereotypes of Indigenous peoples (Furniss, 1999).

Acknowledging the reality of settler colonialism would mean acknowledging the illegitimacy of Canadian nation-state practices. This illegitimacy is why, as Moreton-Robinson et al. (2008) show, the mythology of racelessness means a whiteness, or settler coloniality, that is fed by "cultural imaginaries" of legitimacy and justification for Indigenous subordination (p. 144). To make this mythology visible, this research engages a critical discourse analysis of the media coverage on the TRC in order to unveil some of these racialized and colonialist stereotypes (Ladner \& Tait, 2017).

\section{Memory}

To analyze this mythology — as seen in the racialized rhetoric — is to scrutinize contemporary public collective memories that deny settler colonialism, Indigenous voices, and TRC testimonies. Harris (1993) points out that the power of collective memory is in discarding settler colonialism to the past. She contends,

Current legal definitions interpret race as a factor disconnected from social identity and compel abandonment of race-consciousness. Thus, at the very historical moment that race is infused with a perspective that reshapes it, through race-conscious remediation, into a potential weapon against subordination, official rules articulated in law deny that race matters. (Harris, 1993, p. 1768)

This denial emerges in the complex public discourse on "multiculturalist racelessness" in Canada (Dyer, 2002) and the collective memory of "past" colonialism. This ideology of multiculturalism is used to erase Indigenous presence and leaves exploitative relations and racism intact without looking at the structural inequalities — or instead focuses on immigrant communities while erasing Indigenous peoples and claims.

Public discourses have a direct relationship with the dominant collective memory shaped by settler colonialism (Furniss, 1999). This relationship, or interdependent mechanism, also shapes our interpretation of the TRC. Collective memory narratives make it easier to reinforce existing stereotypes and normative elements through confirmation biasaffirming the collective imaginary in the public sphere - than to denounce or debase them (Furniss, 1999). People are often unable to distinguish between "fiction, reality, fantasy [within] remembered experience" (Barash, 2016, p. 48). Even more problematic is the fact that the fragmented characteristics of memory go unnoticed. These mechanisms of collective 
memory, in combination with the white possessive and properties of the settler colonial nation-state, lead to a fractured paradigm, which in this case study is discernable in the erasure of Indigenous narratives in news sources (Goffman, 1986, pp. 51-9).

This colonial, or "genesis amnesia," allows for repetitive racialized stereotypes to have continued power, and reaffirms the institutionalized racialized belief system connected to the nation-state (Harris, 1993; Moreton-Robinson, 2015; Moreton-Robinson et al., 2008). This historical stereotyping of Indigenous peoples visible in the public sphere makes these stereotypes a contemporary issue with material consequences. The normative structures of the colonial conceptual order create a Canadian "reality" within and through which collective memory is shaped, and settler colonialism, as a narrative, is simultaneously upheld and made invisible through this "reality" (Barash, 2016, p. 48; see also Furniss, 1999).

\section{Methods}

The "genesis amnesia" of the settler colonial rhetoric begets closer scrutiny (Chilton, 2005; Van Leeuwen, 2005, p. 13). Public discourse analysis is an appropriate tool for this research as it exposes the sedimented ideas or knowledge networks that have become normatively ingrained in rhetorical structures. As Fairclough (2005) argues, the importance of a meta-textual analysis is to see the simplifications of "common sense," what is in/excluded, and how these stereotypes are perpetuated. Patterns can be discerned to look at rhetorical structures of settler colonial ideology (Van Dijk, 2005, p. 4).

This case study examines content from five Canadian media platforms that covered the ADR and TRC process between 2003 and 2016. Articles, editorials, and textual references were all included. Search terms summoned were: "TRC," "residential schools," "Truth" AND "Reconciliation," and "ADR." 3 The 1,309 media articles analyzed span Indigenous source Windspeaker $(\mathrm{n}=239),{ }^{4}$ highest readership newspaper Toronto $\operatorname{Star}(\mathrm{n}=222)$, The Globe and Mail (n=318), Winnipeg Free Press $(\mathrm{n}=350)$, and National Post $(\mathrm{n}=180)$. The publications appeared off- and online between January 1, 2003, to December 31, 2016, accessible through ProQuest. The timeframe starts with the launch of the ADR process in 2003 and ends with the publication of the Final Report in 2015. This includes 2016 to allow for an assessment of the direct response to the Final Report published in December of 2015.

\footnotetext{
${ }^{3}$ Acronyms were summoned in acronyms as well as in explication; includes duplicates for on- and offline publication.

${ }^{4}$ Windspeaker does not occupy the same frequency of publication or distribution like the other dailies and newspapers but was nonetheless added as a counter-narrative to the other four sources.
} 
This case study employs discourse analysis methods provided by Fairclough (2005), in combination with frame analysis presented by Snow and Benford (1988) and Benford and Snow (2000) to analyze how people have represented the TRC in the media platforms selected. As Allen (2017) explains, "frame analysis offers a theoretical, methodological, and critical tool for exploring processes of meaning making and influence among governmental and social elites, news media, and the public" (p. 584). In paraphrasing research by Stephen Reese and Robert Entman, Allen (2017) illustrates how a frame is a "socially shared organizing principle" which "influence public opinion by creating and promoting particular vocabularies" (p. 584). It is these particular vocabularies that are scrutinized here as being shaped by settler colonialism. Though not exhaustive, five news platforms were vetted for publications related to the IRS and TRC through a qualitative analysis in which frames were analyzed. The coding was conducted through labeling and organizing how the TRC is represented to identify different themes and the relationships between them. Results were signified as diagnostic, prognostic, or motivational, and categorized as positive, neutral, or negative, as explained in more detail below. By coding the sources extracted through ProQuest, common themes emerged that are made part of a thematic analysis through the concepts of whiteness and colonial denial.

The strategy of discourse analysis that addresses semantic memory in public discourse is what Van Dijk (2005) calls the analysis of the "cognitive device" (pp. 76) - or collective memory - shaped by ongoing perceptions and cultural knowledge (pp. 83-4). This cognitive device is racialized and accessible by those with "preferential access to public discourse," making media racialized and highly influential in reaffirming people's knowledge (Van Dijk, 2005, p. 88). Dominance in public discourse, therefore, allows for abuse of knowledge and the assumption of information that fits the cognitive device or pre-existing collective memory as the "truth."

The discourse analysis of articles on the ADR and TRC allows for the mapping of different rhetorical patterns or "truths." According to Goffman (1986), the meaning of a pattern (frame) implicitly has cultural roots or context-dependency, which in this case study is shaped by Canadian settler colonialism and simultaneous denial thereof. The settler colonial mechanism has relative absolute power within the organizational structures and the bureaucratic system, and can be analyzed through the appearance of harmful tropes, as well as the erasure of the settler colonial ideology in perpetuating those tropes.

Discourse analysis is a particularly critical element of understanding the collective cognitive device, and newspaper articles allow me to analyze "genesis amnesia" of settler colonialism in Canada (Chilton, 2005, pp. 19-21). The cognitive approach proposed by 
Chilton (2005) assesses racialization explicitly as related to the "order of public discourse" (p. 20). This cognitive conceptualization problematizes the "common sense" discourse that erases settler colonialism. It connects negative stereotypes and symbolic violence embedded in the newspaper sources with the genesis amnesia of settler colonialism and explains why denial resonates more than Indigenous testimony (pp. 21-2).

The use of Chilton's (2005) approach allows the inclusion of a cognitive dimension that actively maps the connection of text to the construction of knowledge about social subjects, identities, and processes through a collective mind (p. 23). This collective mind reveals racism in the public sphere and responses of white rage and fragility (Anderson, 2016; DiAngelo, 2018). These reactionary push back responses to the TRC process show how racialized mechanisms are persistent and, in turn, denied, or render emotional responses. Because settler colonialism is erased and "racism" is seen as taboo (Anderson, 2016; DiAngelo, 2018; Harris, 1993), existing cognitive patterns in the public sphere do not engage with structural "issues" beyond supposedly mere "Indigenous issues." The public erases or reinforces institutional racialization of Indigenous people, which perpetuates colonial denial to avoid white guilt or accountability.

Frame analysis, as introduced by Goffman (1986), allows a mapping of the frames and cognitive devices that justify colonial denial. The assessment of frames that align settler colonialism as in the past, or the TRC apology as the end of the IRS legacy, helps unpack the racialized settler colonial tropes in public discourse. The direct erasure of settler colonial reality is, as discussed through the white possessive, an inherent mechanism of settler colonialism that becomes visible through erasure in everyday newspaper articles.

My analysis of these media platforms revealed public confusion, concern, and bias towards the IRSSA and TRC process. Recurring negative stereotypes and tropes emerge in the sources framing Indigenous leadership, people, and communities involved as depraved, inferior, and resistant to progress (Clark, 2014; Environics Institute for Survey Research, 2016; Francoeur, 2018). The recurrence of these pre-existing stereotypes is problematic as stereotypes come with material and immaterial consequences for those implicated in the stereotypes (Smith, 2009). These historical tropes actively shape and form part of the broader public discourses that perpetuate settler colonialism and Indigenous subjugation. 


\section{Case Study}

For this study I focused on narrative framing, specifically the diagnostic, prognostic, and motivational frames (Snow \& Benford, 1988). These frames are assigned when one of the summoned terms - for instance "TRC" or "Indian Residential School" - was mentioned in the text. The frames were broken down by rhetorical purpose and counted. The figures in this article offer a quantitative aspect to visualize the distribution of rhetoric frames in the sources.

Diagnostic frames often mention the residential schools to not only identify the problem, but more so to assign blame. An example sentence would be, "The churches and the Canadian government were responsible for the residential school system." Prognostic frames suggest solutions, strategies, and tactics to the identified problem or liable actor(s), for example, "the residential school system needs to be assessed by the TRC." Finally, motivational frames reveal a more active rationale to mobilize (future) action to deal with the problem or liable actor(s), such as "the TRC has to educate and create general awareness among the Canadian public for Indigenous and non-Indigenous relations to heal." These three ideal frames often overlap or coexist.

As mentioned, the media coverage spans 1,309 sources published between 2003, with the launch of the ADR process, through to 2016 after the publication of the TRC's findings. The sources were collected through ProQuest and crosschecked with the newspapers' websites. In the 1,309 sources, multiple diagnostic, prognostic, and motivational frames were counted to reveal related imaginaries, framing, and rhetorical significations. Total coded and counted frames $(\mathrm{n}=2,270)$ per media source are: Windspeaker $(\mathrm{n}=475)$, Toronto Star $(\mathrm{n}=356)$, The Globe and Mail ( $\mathrm{n}=559)$, National Post $(\mathrm{n}=346)$, and Winnipeg Free Press $(\mathrm{n}=534)$. For example, the National Post from 2003 to 2016 contained 180 articles which mention the ADR, TRC, or IRS system, resulting in 346 frames (Figure 1). 


\section{Counted frames related to residential schools in Canada from $2003-2016$}

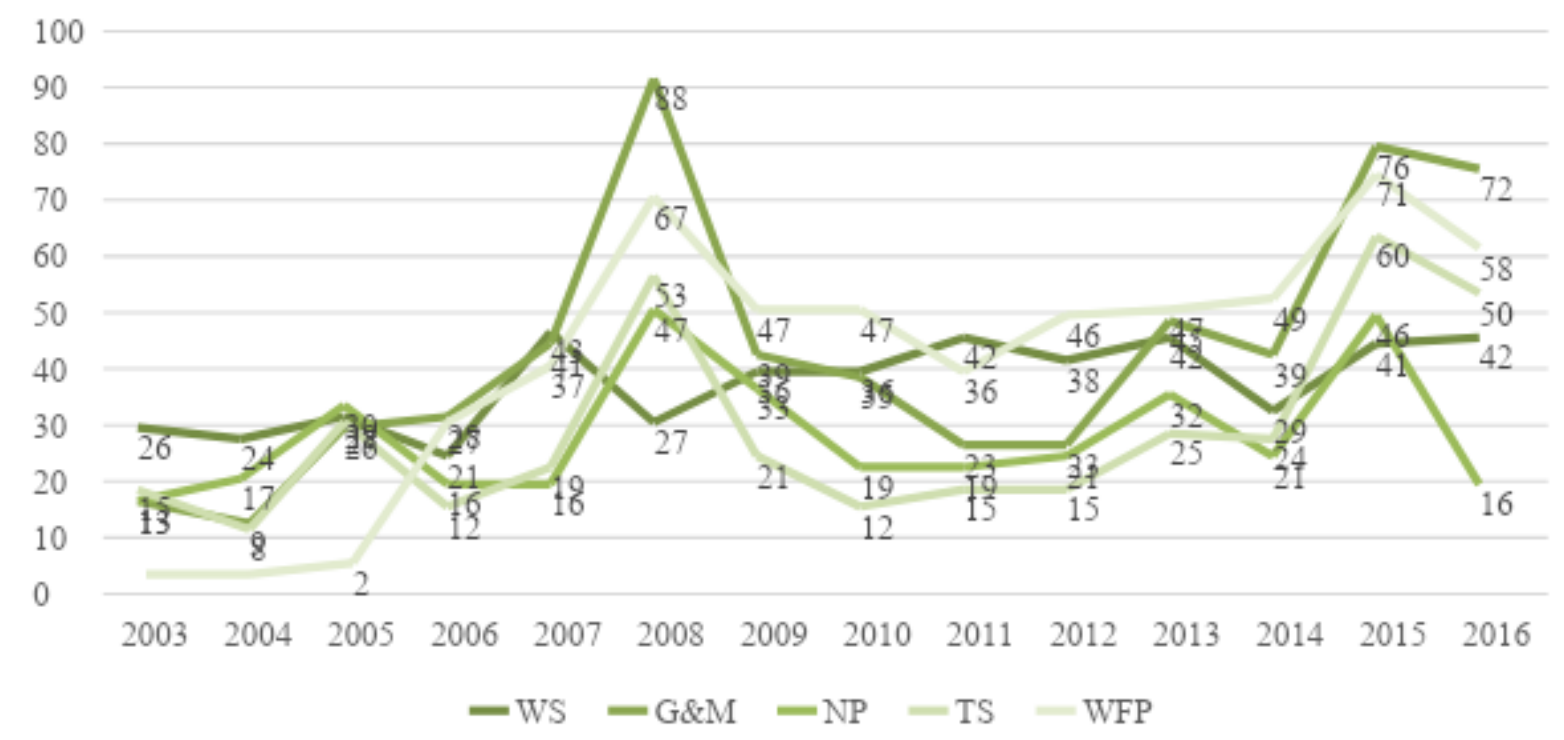

Figure 1: Numbers per platform, 2003-2006: Windspeaker (WS), The Globe and Mail (G\&M), National Post (NP), Toronto Star (TS), and Winnipeg Free Press (WFP).

Importantly, this case study reaffirms how the different frames used by Snow et al. (2007) — diagnostic, prognostic, and motivational — are ideal types that, alone, do not adequately unpack the complex framing of the TRC in media coverage. Apart from frames being diagnostic, prognostic, or motivational, the newspaper sources reveal that these frames can also be negative, neutral, or positive (Figure 2). For example, the prognostic solutions, strategies, and tactics related to ADR money in terms of the TRC process can be negative, neutral, or positive-e.g., "the TRC should not give survivors so much money" (negative); "one of the TRC's mandated action points is providing settlement funds" (neutral); or "the money is a welcome acknowledgment in the process of the TRC for IRS survivors" (positive). These negative, neutral, or positive significations of each frame also have context dependency, as a negative prognostic frame in Windspeaker is different from a negative prognostic frame in the National Post regarding the ADR and TRC process. 


\begin{tabular}{|c|c|c|c|c|c|}
\hline $\begin{array}{l}\text { Diagnostic } \\
\text { frames }\end{array}$ & & $\begin{array}{l}\text { Prognostic } \\
\text { frames }\end{array}$ & & $\begin{array}{l}\text { Motivational } \\
\text { frames }\end{array}$ & \\
\hline Church & Liability & Money & Process & Healing & Action \\
\hline Government & Liability & Arts & Process & $\begin{array}{l}\text { TRC + Calls } \\
\text { to Action }\end{array}$ & $\begin{array}{l}\text { Action } \\
\text { solution }\end{array}$ \\
\hline Colonialism & Structural & $\begin{array}{l}\text { Education: } \\
\text { teaching }\end{array}$ & $\begin{array}{l}\text { Suggested } \\
\text { solution }\end{array}$ & $\begin{array}{l}\text { Awareness } \\
\text { education }\end{array}$ & Rationale \\
\hline $\begin{array}{l}\text { Intergenerational } \\
\text { Trauma }\end{array}$ & Structural & $\begin{array}{l}\text { Going to } \\
\text { trial/TRC }\end{array}$ & Strategy & $\begin{array}{l}\text { Settlement of } \\
\text { process }\end{array}$ & $\begin{array}{l}\text { "Award" } \\
\text { Solution }\end{array}$ \\
\hline Indian Act & Structural & $\begin{array}{l}\text { Self- } \\
\text { governance }\end{array}$ & Strategy & & \\
\hline $\begin{array}{l}\text { Survivor story } \\
\text { Historical reality }\end{array}$ & $\begin{array}{l}\text { Identification } \\
\text { General }\end{array}$ & & & & \\
\hline
\end{tabular}

Figure 2: Frames and rhetoric structures found, 2003-2016. Note that these appear in negative, neutral, and positive connotations with Indigenous communities and people.

The discerned frames reveal that four papers, excluding Windspeaker, cover the official apology by the Canadian government and some of the church entities most extensively. Apart from the focus on the apology these four platforms, to a different extent, frame the TRC process as another financial handout by the government and only sparsely acknowledge the traumatic experience for IRS survivors and their families. In contrast, Windspeaker frames the money assigned for the ADR and TRC process as a complicated and convoluted process. Windspeaker articles talk about how church and government documents are not released, thereby making survivors unable to prove their previous enrolment and requiring survivors to prove and perform the "level" of abuse and trauma. Windspeaker problematizes the process, covering issues such as untrustworthy lawyers, and bureaucratic and administrative disasters that put the onus of proof on survivors. These narratives are absent in the other four newspapers.

The four newspapers, excluding Windspeaker, often frame the court proceedings and money allotment issues as another opportunistic scheme for Indigenous people. As seen in Figure 2, the "award" narrative points to the ADR money as a "winning solution." The Globe and Mail, Winnipeg Free Press, and the National Post portray monetary compensation as a motivational frame, or overall solution, for the IRS legacy; they do not contemplate the settler 
colonial structure of Canada. The TRC process and monetary compensation connect with the myth that Indigenous peoples are perpetually receiving money from the government, rather than critically assessing structural settler colonial subjugation. This myth reveals a lack of critical engagement in these four newspapers based on inherent rhetorical differences in framing Indigenous "issues," broadcasted to their respective audiences.

In generalized observation, The Winnipeg Free Press moves from being outraged about the hegemonic political structure and the "shameful" IRS legacy from 2003-2008, to apathy and indifference from 2008-2015, to more reactive activist narratives in 2015. This reactive populist writing-style seems connected to unawareness or naiveté concerning the colonial structural underpinnings that made the IRS possible. Consequently, this diagnostic framing places blame and guilt in the past and suggests the need for people to "just move on," which fails to address the need for accountability in the context of continued settler colonialism in Canada.

Windspeaker, as indicated before, is overall more critical of the federal government and connects the IRS to intergenerational trauma, broken treaties, the Sixties Scoop, and thus as part of structural societal problems that require healing and reconciliation. The Toronto Star reveals a more critical and diverse coverage of the ADR and TRC process and, at times, moves away from the obsession with government apology and monetary settlement alone, especially with the publication of the Final Report in 2015 as "proof" of the IRS reality and legacy.

The Globe and Mail reveals racialized rhetoric more overtly and features biased coverage against Indigenous peoples. The focus is on the ADR monetary compensation through the court. Leading columnist Margaret Wente expresses the overall tendency of the paper that aligns traumatic past with settler colonial rhetoric and Indigenous stereotypes. On April 25, 2006 she wrote, "But how do you move on? How do you make peace with the modern world when you are haunted by ancient wrongs and obsessed with a romantic version of an idealized past?" (Wente, 2006). Unpacking this narrative reveals the idea that Indigenous people are part of the historical past, are not modern or unable to adequately adapt, and are "obsessed with a romantic past."

The National Post portrays the most stereotypes regarding Indigenous communities implicated in the ADR and TRC process. Overall, coverage is scarce and more concerned with the fate of the church entities involved in the liability process. Notably, the National Post questions Indigenous survivor claims. The narrative focuses on the notion that residential schools could not have been all bad, as they provided free education to Indigenous subjects. On December 5, 2003, freelance writer Elizabeth Nickson writes, "The residential schools 
certainly started out in the minds of the then church bureaucrats as the right thing to do. We're still paying. Indians [sic] own part of the blame, because boy, do they know how to work it" (Nickson, 2003). Not only does Nickson call Indigenous people "Indians," she also blames Indigenous people in the TRC process of "working the situation." The National Post and The Globe and Mail provide the platforms that most obviously display the recitation of three tropes: framing Indigenous people as depraved, inferior, and as resistant to progress (Clark, 2014; Francoeur, 2018). These rhetorical patterns discerned through the diagnostic, prognostic, and motivational frames reveal how historical racialized stereotypes are repeated in these journalistic and editorial narratives.

These negative tropes are less pervasive when the overall coverage on the TRC increases during the 2008 apology and the 2015 release of the TRC's Final Report. The year 2008 sees an increase in optimism related to the formal apology, and in 2015 there is an increase in sorrow upon release of the Final Report and Calls to Action. Visualized in Figure 1, the number of articles spike during 2008 and 2015. Interestingly, the intermediate period and the period after 2015 reveal how the apathy and indifference for the TRC return (Figure $3)$.

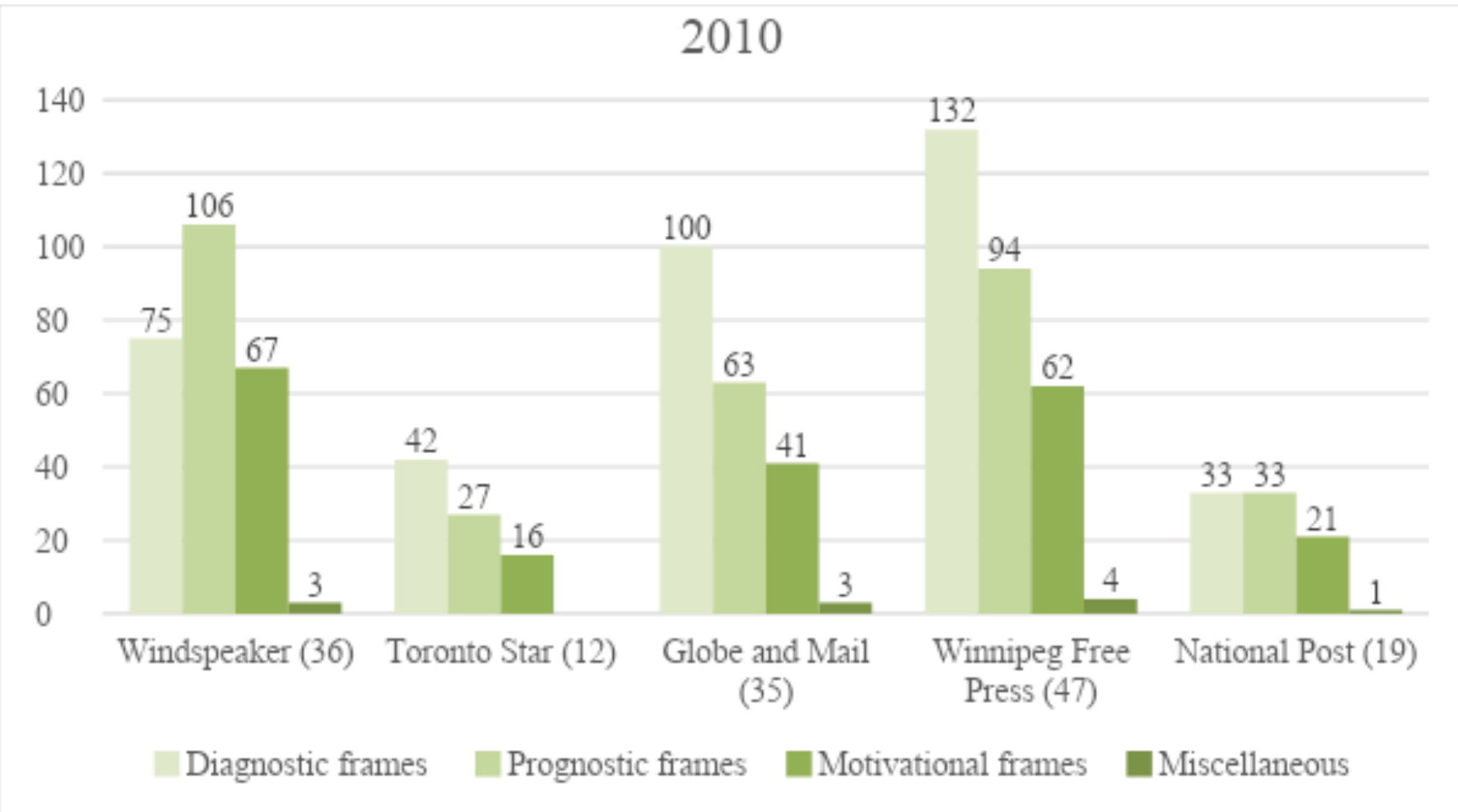

Figure 3: Overview of frames as analyzed in articles for 2010 regarding the TRC and residential schools coverage. 
This indifference could be explained by the limited presence of motivational or prognostic frames to engage with the TRC's findings, in which the narrative gets stuck in diagnostic frames and questions of guilt and blame. After 2015 and the end of the TRC mandate, public interest diminished once again. A lack of proposed action or outrage from people within the larger belief system failed to garner action or even publicity (Tarrow, 1993). The narrative thus reverted to the stereotypes regarding Indigenous "problems" and negative reliance on government help and enumeration.

The analyzed sources indicate negative discursive framing and stereotyping of the Indigenous "Other" as a "problem" that is hard to capture through frame analysis alone. The stereotypes present in these articles nevertheless tell us something about the readership. The most prevalent recurring frames are usually the narratives that resonate with the intended audience and reveal the symbolic communication between the audience, the larger belief system, and editorial staff (Benford \& Snow, 2000; Goffman, 1986; Snow \& Benford 1988). It seems that the public discourse, although predominantly shaped by settler colonialism, does consistently erase this settler colonial reality in the coverage on the TRC in four out of five platforms under analysis here, in line with the scholarship by Harris (1993), Smith (2012), Moreton-Robinson et al. (2008), and Moreton-Robinson (2015).

Interestingly, settler colonial bias seems to function somewhat independently of the four newspapers' political affiliation, although the more conservative newspapers seem to invite a more outright denial of settler colonialism and denouncement of IRS survivors. Windspeaker is shaped by the Aboriginal Multi-Media Association connected to the political party in government office, and their focus seems to be on the possible constructive relationship between that party and the Assembly of First Nations (AFN) ("A recipe for success," 2006). The Toronto Star displays a liberal political affiliation in the editorials in 2006, 2008, and 2011, and endorsed the Liberal Party election program (Toronto Star endorses Liberal Leader," 2015). The Winnipeg Free Press, although not sporting an explicit party endorsement, can be seen as slightly conservative based on editorials (2006, 2008, 2011, 2015). The Globe and Mail appears conservative in editorials from 2006, 2008, and 2011 and is connected to the Woodbridge company that endorsed the Conservative Party, though it did not specifically endorse the re-election of Conservative Party leader and then-Prime Minister Stephen Harper ("Global and Mail mocked," 2015). The National Post is staunchly conservative, and its parent company, the Postmedia Network, endorsed the Conservative Party and denied its assets from endorsing other parties ("Andrew Coyne resigns," 2015). Further elaboration of this alignment of political affiliation with the level of settler colonial denial should be explored in additional research. 


\section{Assessment}

The newspaper articles I analyzed perpetuate negative stereotypes regarding the TRC process and Indigenous peoples. These public texts reveal how predominantly non-Indigenous Canadian writing displays settler colonialist perceptions while failing to account for these perceptions to their respective audiences. Surprisingly little attention goes to IRS survivors or the testimonies given to the TRC commission (except for Windspeaker). When these personal experiences are included, they often need to be corroborated by other testimonies or nonIndigenous interpretation. As Barash (2016) elucidates, "far from recapitulating reality in some absolute sense of the term, [personal experiences] must constantly be complemented and corrected by other testimonies" (p. 44). This need for truth in testimony that is present in these articles burdens survivors to convince the Canadian public. "Truth," this analysis shows, resides with the majority, and not in the minority counter-narrative to the larger belief system (Wilson, 2001).

The veracity required in testimony in order to challenge this larger belief system reveals another ambiguity in public discourse and collective memory regarding the TRC. For example, majority-based "large-scale public commemorations...recall what is beyond any possibility of remembrance by those who participate in them since [these memories] most frequently lie beyond the possibilities of what any living individual might have experienced and remembered" (Barash, 2016, p. 44). Strangely enough, this majority-based collective memory of non-Indigenous rhetoric is idealized as more "true" than the actual living traumatic personal testimony and experiences of IRS survivors, as these real experiences do not align with settler colonial ideology and myths (Barash, 2016, p. 45; see also Nickson, 2003).

While there are additional layers of the settler colonial collective cognitive device that could be analyzed, the discourse analysis here makes clear the absence of accountability in four out of the five platforms. Critical ADR and TRC processes that put a negative light on settler colonial ideology are filtered out. The non-cooperative stance of the government and church entities in providing documentation for the TRC testimonies, as well as insufficient funds allocated to the overall process, are left out of their media coverage. Instead, these procedural fallacies are seen as neglect on the part of the TRC or Indigenous people involved. The notion that Indigenous peoples depend on federal funding remains, which continuously erases the colonialist structures that created and perpetuate these "dependencies."

For example, the struggles with the legal system for IRS survivors and their families are mostly ignored. In the 2003-2008 period, only Windspeaker addressed the class-action 
lawsuit settlements critically, focusing on the deflective and evasive approach government took to acknowledging the volume of IRS survivors involved. The other four platforms instead focused on the organizational setbacks generated by the initial TRC commissioners' resignations. Issues that arose as a result of church entity and government evasive maneuvers were neglected and stocked up to mismanagement on the part of the TRC commissioners, coupled - again — with imaginaries of Indigenous moneygrubbing (Environics Institute for Survey Research, 2016, p. 11). ${ }^{5}$

Newspaper rhetoric surrounding the TRC primarily focused on the official apologies. That is, even though the TRC commissioners conducted nationwide community hearings across Canada, disbursed funding for commemoration activities across the county, and created permanent commemoration and research facilities for document storage, mainstream media focused on the official apology. They quickly lost interest until the Final Report in 2015. The newspaper analysis thereby reveals that "action," perceived in the public sphere, is mostly apologetic. The IRS and its legacy are thus not connected to unaddressed structural issues of settler colonialism experienced by Indigenous peoples (see, for example, Wyld, 2015).

Another narrative that emerged from this analysis is that reconciliation is expected mostly from Indigenous communities and peoples themselves. The general narrative of apology and reconciliation does not often include a role, or an expectation of accountability, for the general Canadian population. The idea of an "Indian problem" rather than a "Canadian problem" or "settler colonial problem" prevails, and newspaper letters to the editor at times reveal a fed-up public that seeks to "just move on" (Eshet, 2015). The "problem" is thus rhetorically only solved through apologies and denial of the underlying structural issues.

The lack of critical engagement with the TRC, as shaped by the structural settler colonialist system in Canada, seems to absolve non-Indigenous audiences from introspective engagement. Although the settler colonial system present in Canada shaped the IRS, ADR, and TRC processes as well as permeated the lives of all Canadians, the truth-telling and healing are deemed only a part of Indigenous reconciliation with the past and present trauma. According to the mandate, "the truth-telling and reconciliation process as part of an overall holistic and comprehensive response to the Indian Residential School legacy is a sincere indication and acknowledgement of the injustices and harms experienced by Aboriginal people and the need for continued healing" (Truth and Reconcilliation Comission, 2008). This continued healing mandate is met with a denial of settler colonialism in the public sphere,

\footnotetext{
${ }^{5}$ For a general report on myths regarding Indigenous economics, see also: TD Economics. (2012). Special report: Debunking myths surrounding Canada's Aboriginal population. www.td.com/document/PDF/economics/special/sg0612_aboriginal_myth.pdf
} 
mistakenly making the work of healing a process for Indigenous peoples or survivors and their families alone. The TRC mandate and the 94 Calls to Action seek "to redress the legacy of residential schools and advance the process of Canadian reconciliation" (Truth and Reconilliation Commission, 2015b). However, this is incomplete without due diligence by the majority of the population to acknowledge continuous participation in - and damage done by—a settler colonial society.

\section{White Fragility and Rage}

As discussed through the work of Harris (1993), Moreton-Robinson et al. (2008), and Moreton-Robinson (2015) on the white possessive, this newspaper analysis reveals the settler colonial reality through the invisibility of settler colonial reality in the TRC process. Importantly, this case study contributes to the academic literature by highlighting the ways in which a settler colonial narrative and larger belief system in Canada justify the continuous negative stereotypes of Indigenous peoples (Wolfe, 2006, p. 389). The written content from four out of five Canadian media platforms regarding the ADR and TRC affirms the rhetorical pattern of denial and erasure. Visible rhetorical patterns reaffirm stereotypes and (c)overtly reaffirm the settler colonial legitimacy.

Specifically, the sources analyzed do not engage with how the racialization of the Canadian state shapes settler colonial rhetoric and reality. Scholarship based on the Black/white divide from the United States can be applied to analyze the racialization of the Canadian state. According to DiAngelo (2018), racialization is caused by the cognitive map or network of white fragility. Applied to Canada, this could mean that settler colonial denial, or an inability to assess racism, is shaped by the collective beliefs that prevent the public from "seeing" racism in favor of multiculturalism (St. Denis, 2011). In similar ways, settler colonialism and racialization are rendered invisible. This invisibility of the settler colonial reality is a system that upholds the white possessive. As DiAngelo (2018) substantiates, racism is wrongfully aligned with personal character traits; in similar ways, settler colonialism is connected to previous generations' "bad behaviour." To be racist - or settler colonialmeans to be a bad person based on a conscious choice of dislike of the "Other." This reasoning negates a critical assessment of racialized structures and settler colonialism. Pushing against this collective deflection may be met with white rage and further denial of settler colonialism or the white possessive (Anderson, 2016). 
It is important to note that both white rage and white fragility, as defined by Anderson (2016) and DiAngelo (2018) refer to a Black and white divide in the United States. Similarly, Moreton-Robinson et al. (2008) and Moreton-Robinson (2015) write about Australia's white possessive in relation Indigeneity as "blackness." This qualitative discourse analysis of the TRC process in Canada shows that these mechanisms can apply to the Canadian discourse, and that more scholarship into Canadian "whiteness" is required. The Canadian negative stereotypical tropes similarly denounce their inherent racism and settler colonialism. Rather than acknowledge a structural problem of settler colonialism, the sources analyzed seem to either deflect responsibility or, at times, internalize the TRC's findings as an attack on their humanity (Anderson, 2016; DiAngelo, 2018). DiAngelo (2011) describes these negative stereotypes as the repetitive response "white people exhibit when they are told they are complicit in society's institutional racism" (p. 55; see also Iqbal, 2019). Similarly, four out of five media platforms analyzed - The Globe and Mail and National Post most explicitlydeflect any critical assessment of settler colonialism and instead reaffirm colonial denial and white privilege, which results in a politics of silence and an erasure of colonial realities.

White rage, in relation to the white possessive, can be further applied in Canada to analyze the ongoing erasure of Indigenous peoples and the denial of colonialism. As Anderson (2016) explains with regards to the American context, "the trigger for white rage, inevitably, is black advancement. It is not the mere presence of black people that is the problem; rather, it is blackness with ambition, with drive, with purpose, with aspirations, and with demands for full and equal citizenship. It is blackness that refuses to accept subjugation, to give up" (p. 3). This white rage might be visible in Canada with response to Indigenous resistance and testimony in the TRC process by, for instance, Nickson (2003) in the National Post, when she framed the ADR and TRC processes as Indigenous money schemes instead of a process of healing from government-sanctioned trauma.

\section{Conclusion}

This study set out to analyze the rhetoric surrounding the TRC process as five Canadian media platforms covered it. My analysis seeks to uncover the operations of a rationale in public discourse, represented by, for instance, the ability of the Harper government to simultaneously apologize for the residential schools in Canada, as well as deny settler colonialism. This paper has argued that, through a frame analysis of the diagnostic, prognostic, and motivational frames across news platforms, there is a rhetorical contradiction 
in which apologies and reaffirmation of settler colonial narrative co-exist as part of a broader public narrative of colonial denial in Canada. Frame analysis, supplemented with qualitative discourse analysis, provides clear insights into the role media coverage plays in the cognitive erasure of settler colonialism, and makes clear the need for additional research into Canadian racialization, colonial denial, and whiteness.

Settler colonial denial is significant in the specific case study of the TRC process, as the TRC acquired thousands of testimonies that directly contest this settler colonial denial. Despite the apparent settler colonial reality presented by the IRS testimonies of survivors, four out of five of the newspapers analyzed did not engage with these testimonies but instead, at times, reinforced negative stereotypes and tropes regarding Indigenous peoples and communities that have been visible since the $19^{\text {th }}$ century. The collective memory of settler colonial and immigrant rhetoric of a raceless, multicultural, and non-colonial Canada is idealized as more "true" than the actual traumatic personal testimony and experiences of IRS survivors. Settler colonial ideology and myths are upheld by, and fall back onto, the cognitive networks already in place. These cognitive networks reinforce the imaginary of Indigenous peoples as depraved, inferior, and as resistant to progress, and the Canadian nation-state as a multicultural, progressive, and just society.

This research reveals non-Indigenous apathy beyond formal apology, and how this apathy aligns with the overall obscuring of the structural mechanisms of settler colonialism. When situated in the academic research on settler colonialism, this case study shows how public discourse continuously reinforces the denial of colonialism and the disappearance of Indigenous peoples in Canada. This is similar, my analysis shows, to the denial of racism and realities of white fragility and white rage described by scholars in the American and Australian contexts.

Overall, this study shows the importance of looking at media beyond the scope of their initial "news factor" of daily coverage by examining the symbolic and textual representation of "issues" and continuous tropes. The findings of this research provide a reconceptualization for doing frame analysis and the tools needed for a critical discourse methodology that include the careful consideration of cognitive mapping as put forward by Chilton (2005). While this study raises important questions about the nature of the public sphere in perpetuating settler colonialist narratives while simultaneously denying its existence, further critical deconstruction of the establishment of "common sense ideas" is needed. This could be done, for example, by differentiating between the social constructions and the cognitive mapping of "common sense" that occur to justify the denial of settler colonialism in Canada. By 
deconstructing "common sense" in Canada, a clearer understanding of the erasure of settler colonialism by colonialist discursive frames in our publics is possible.

\section{References}

Allen, M. (2017). The Sage encyclopedia of communication research methods (Vols. 1-4). Thousand Oaks, CA: SAGE Publications.

Andersen, C. \& Walter, M. (2013). Indigenous statistics: A quantitative Indigenous methodology. Routledge, Left Coast Press.

Anderson, C. (2016). White rage: The unspoken truth of our racial divide. New York, NY: Bloomsbury USA.

Andrew Coyne resigns as National Post comment editor after paper rejects election column. (2015, October 19). CBC News. Retrieved from www.cbc.ca

Barash, J. A. (2016). Collective memory and the historical past. Chicago, IL: The University of Chicago Press.

Benford, R. D., \& Snow, D. A. (2000). Framing processes and social movements: An overview and assessment. Annual Review of Sociology, 26(1), 611-639. doi:10.1146/annurev.soc.26.1.611

Brady, M. J., \& Kelly, J. M. H. (2017). We interrupt this program: Indigenous media tactics in Canadian culture. Vancouver, BC: UBC Press.

Carter, S. (1990). Lost harvests: Prairie Indian reserve farmers and government policy. Montreal, QC: McGill-Queen's University Press.

Casey, M. (2008). Chapter 2: Managing resistance: Whiteness and the storytellers of Indigenous protest in Australia. In: Transnational whiteness matters, edited by Aileen Moreton-Robinson, Maryrose Casey \& Fiona Nicoll. Lanham, MD: Lexington Books

CBC News. (2014, Jan 7). Residential school deaths. [Video file.] Retrieved from https://www.cbc.ca/news/canada/residential-school-deaths-1.2487930

Chilton, P. (2005). Chapter 2: Missing links in mainstream CDA: Modules, blends and the critical instinct. In R. Wodak \& P. Chilton (Eds.), A new agenda in (critical) discourse analysis: Theory, methodology and interdisciplinarity. Amsterdam, NL: John Benjamins.

Clark, B. (2014). Framing Canada's Aboriginal peoples: A comparative analysis of Indigenous people and mainstream television news. Canadian Journal of Native Studies, 34(2), 4164. 
DiAngelo, R. J. (2011). White fragility. International Journal of Critical Pedagogy, (3), 5470.

DiAngelo, R. J. (2018). White fragility: Why it's so hard for white people to talk about racism. Boston, MA: Beacon Press.

Dunbar-Ortiz, R., \& Gilio-Whitaker, D. (2016). "All the real Indians died off”: And 20 other myths about Native Americans (Xwi7xwa Collection). Boston, MA: Beacon Press.

Dyer, R. (2012). “The matter of whiteness". In P. S. Rothenberg (Ed.), White privilege: Essential readings on the other side of racism (4th ed.) (pp. 9-14). New York, NY: Worth Publishers.

Environics Institute for Survey Research. (2016). Canadian public opinion on Aboriginal people: Final report. (2016). Retrieved from the Environics Institute for Survey Research website: https://www.environicsinstitute.org/docs/default-source/projectdocuments/public-opinion-about-aboriginal-issues-in-canada-2016/finalreport.pdf?sfvrsn=30587aca_2

Eshet, D. (2015). Stolen lives: The Indigenous peoples of Canada and the Indian residentials schools. Canadian Public Documents Collection. Toronto, ON: Facing History and Ourselves.

Fairclough, N. (2005). Chapter 3: Critical discourse analysis in transdisciplinary research. In R. Wodak \& P. Chilton (Eds.), A new agenda in (critical) discourse analysis: Theory, methodology and interdisciplinarity. Amsterdam, NL: John Benjamins.

Fisher, R. (1980). Contact \& conflict: Indian European relations in British Columbia. Burnaby, B.C: Simon Fraser University.

Francoeur, M. (2018). Reconciliation in the news: A framing analysis of residential schools and the TRC in Canadian national newspapers (Unpublished doctoral dissertation)., Royal Roads University: Victoria, BC, Canada.

Furniss, E. (1999). The burden of history: Colonialism and the frontier myth in a rural Canadian community. Vancouver, BC: UBC Press.

Goffman, E. (1986). Frame Analysis: An Essay on the organization of experience (2 ${ }^{\text {nd }}$ ed.). Boston, MA: Northeastern University Press.

Government of Canada. (2018). Nation Rebuilding Program: 2019 to 2020. Retrieved April $15^{\mathrm{t}}, 2018$ from Government of Canada website: https://www.rcaanccirnac.gc.ca/eng/1576604944709/1576604975915

Harris, C. I. (1993). Whiteness as property. Harvard Law Review, 106(8), 1707-1791. 
Holmes, C., Hunt, S., \& Piedalue, A. (2014). Violence, colonialism and space: Towards a decolonizing dialogue. ACME: An International E-Journal for Critical Geographies, 14(2), 539-570.

Indian Act (R.S.C., 1985, c. I-5 [1876]) Act last amended on 2017-12-22. Retrieved from Justice Laws website: http://laws-lois.justice.gc.ca/eng/acts/i-5/page-1.html\#h-331716

Indian Residential Schools Settlement Agreement (IRSSA). (2007). Retrieved from Government of Canada website: www.aadncaandc.gc.ca/eng/1100100015576/1100100015577\#sect1

Iqbal, N. (2019, February 16). Academic Robin DiAngelo: "We have to stop thinking about racism as someone who says the N-word." The Guardian. Retrieved from www.theguardian.com

Ladner, K. L., \& Tait, M. J. (2017). Surviving Canada: Indigenous peoples celebrate 150 years of betrayal. Winnipeg, MB: ARP Books.

Little, W., \& McGivern, R. (2016). Chapter 11: Race and Ethnicity. In W. Little, Introduction to Sociology: 2nd Canadian edition. BCcampus Open Access.

Loppie, S., Reading, C., \& de Leeuw, S. (2014). Social Determinants of Health: Indigenous experiences with racism and its impacts. Public Health Agency of Canada. Retrieved from National Collaborating Centre for Indigenous Health website: https://www.nccih.ca/495/Indigenous_experiences_with_racism_and_its_impacts.ncci h?id=131

McLellan, A. (2005). Indian Residential Schools Resolution Canada 2004-2005 Departmental Performance Report. Retrieved from Government of Canada website:

http://publications.gc.ca/site/archiveearchived.html?url=http://publications.gc.ca/collections/collection_2012/sct-tbs/BT31-489-2005-eng.pdf

Milloy, J. S. (1999). A national crime: The Canadian government and the residential school system. Winnipeg, MB: University of Manitoba Press.

Moreton-Robinson, A., Casey, M., \& Nicoll, F. J. (Eds.). (2008). Transnational whiteness matters. Lanham, MD: Lexington Books.

Moreton-Robinson, A. (2015). The white possessive: Property, power, and Indigenous sovereignty. Minnesota, MN: University of Minnesota Press.

Mudde, L. (2018). Structural genocide and institutionalized racism in Canada: The Department of Indian Affairs and framing of Indigenous peoples. Alberta Academic Review, (1)1. doi:10.29173/aar10. 
National Post. (2003-2016). Accessed through ProQuest March 2018. Search terms: TRC, residential school, ADR, IRSSA.

Nickson, E. (2003, December 5). There's only one Canada -not 630: National edition. National Post, p. A18.

Royal Commission on Aboriginal Peoples. (1996). Report of the Royal Commission on Aboriginal Peoples (5 Volumes). Retrieved from Library and Archives Canada website: https://www.bac-lac.gc.ca/eng/discover/aboriginal-heritage/royal-commissionaboriginal-peoples/Pages/final-report.aspx

Royal Proclamation on the Rights of Aboriginal Peoples. (1982 [1763]). The Constitution Act, 1982, Schedule B to the Canada Act 1982 (UK), 1982, c 11. Part II Rights of the Aboriginal Peoples of Canada. Retrieved from Canadian Legal Information Institute: https://www.canlii.org/en/ca/laws/stat/schedule-b-to-the-canada-act-1982-uk-1982-c11/latest/schedule-b-to-the-canada-act-1982-uk-1982-c-11.html

Smith, A. (2012). Indigeneity, settler colonialism, white supremacy. In D. HoSang, O. LaBennett, \& L. Pulido (Eds.), Racial formation in the twenty-first century. University of California Press.

Smith, K. D. (2009). Liberalism, surveillance and resistance: Indigenous communities in western Canada, 1877-1927. Edmonton, AB: AU Press.

Snow, D. A. \& Benford, R. D. (1988). Ideology, frame resonance and participant mobilization. International Social Movement Research (1), 197-217.

St. Denis, V. (2011). Silencing Aboriginal curricular content and perspectives through multiculturalism: "There are other children here". Aboriginal Policy Research Consortium International (APRCi), 268.

Storey, K. (2016). Settler anxiety at the outposts of empire: Colonial relations, humanitarian discourses, and the imperial press. Vancouver, BC: UBC Press.

Tarrow, S. (1993). Cycles of collective action: Between moments of madness and the repertoire of contention. Social Science History, 17(2), 281-307. doi:10.2307/1171283

The Globe and Mail. (2003-2016). Accessed through ProQuest March 2018. Search terms: TRC, residential school, ADR, IRSSA.

Globe and Mail mocked on Twitter after endorsing Tories but not Harper. (2015, October 16). $C B C$ News. Retrieved from www.cbc.ca

Toronto Star. (2003-2016). Accessed through ProQuest March 2018. Search terms: TRC, residential school, ADR, IRSSA.

Toronto Star endorses Liberal Leader Justin Trudeau for prime minister. (2015, October 9). Toronto Star. Retrieved from www.thestar.com 
Tolley, E. (2016). Framed: Media and the coverage of race in Canadian politics. Vancouver, BC: UBC Press.

Truth and Reconciliation Commission (TRC). (2008). Schedule N of the Indian Residential Schools Settlement Agreement. Retrieved from Truth and Reconciliation Commission of Canada website: http://www.trc.ca/about-us/our-mandate.html

Truth and Reconciliation Commission (TRC). (2012). Truth and Reconciliation Commission of Canada: Interim Report. Retrieved from the Truth and Reconciliation Commission of Canada website:

http://www.trc.ca/assets/pdf/mroom_Interim\%20report\%20English\%20electronic.pdf

Truth and Reconciliation Commission (TRC). (2015a). Honouring the truth, reconciling for the future: Summary of the final report of the Truth and Reconciliation Commission of Canada. PDF. Retrieved from Government of Canada website: http://publications.gc.ca/site/eng/9.800288/publication.html

Truth and Reconciliation Commission (TRC). (2015b). Truth and Reconciliation Commission of Canada: Calls to Action. Retrieved from National Centre for Truth and Reconciliation website: http://nctr.ca/reports2.php

Tuhiwai Smith, L. (1997). Decolonizing methodologies: Research and Indigenous peoples. Zed Books.

Van Dijk, T. A. (2005). Chapter 4: Contextual knowledge management in discourse production: A CDA perspective. In R. Wodak \& P. Chilton (Eds.), A new agenda in (critical) discourse analysis: Theory, methodology and interdisciplinarity. Amsterdam, NL: John Benjamins.

Van Leeuwen, T. (2005). Chapter 1: Three models of interdisciplinarity. In R. Wodak \& P. Chilton (Eds.), A new agenda in (critical) discourse analysis: Theory, methodology and interdisciplinarity. Amsterdam, NL: John Benjamins.

Wente, M. (2006, Apr 25). The politics of protest don't truly empower. The Globe and Mail, p. A17.

Wilkes, R. (2004). First Nation politics: Deprivation, resources and participation in collective action. Sociological Inquiry, 74(4), 570-589.

Wilson, R. A. (2001). The politics of truth and reconciliation in South Africa: Legitimizing the post-apartheid state. Cambridge, UK: Cambridge University Press.

Windspeaker. (2003-2016). Accessed through ProQuest March 2018. Search terms: TRC, residential school, ADR, IRSSA.

A recipe for success. (2006, April 12). Windspeaker. Retrieved from https://ammsa.com/publications/windspeaker/recipe-success 
Winnipeg Free Press. (2003-2016). Accessed through ProQuest March 2018. Search terms: TRC, residential school, ADR, IRSSA.

Wyld, A. (2015, June 4). Clifton \& Rubenstein: Debunking the half-truths and exaggerations in the Truth and Reconciliation report. National Post. Retrieved from www.nationalpost.com

Wodak, R. \& Chilton, P. (Eds.). (2005). A new agenda in (critical) discourse analysis: theory, methodology and interdisciplinarity. Amsterdam, NL: John Benjamins.

Wolfe, P. (2006). Settler colonialism and the elimination of the native. Journal of Genocide Research, 8(4), 387-409. doi:10.1080/14623520601056240. 